\title{
Antibody to human $\alpha$-fetoprotein inhibits cell growth of human hepatocellular carcinoma cells by resuscitating the PTEN molecule: in vitro experiments
}

\author{
KIYOSHI OHKAWA ${ }^{1}$, TADASHI ASAKURA ${ }^{2}$, YUTAKA TSUKADA ${ }^{3}$ and TOMOKAZU MATSUURA ${ }^{4}$ \\ ${ }^{1}$ Stable Isotope Medical Applications Laboratory, ${ }^{2}$ Radioisotope Research Facilities, Research Center for Medical Science, \\ Jikei University School of Medicine, Minato-ku, Tokyo 105-8461; ${ }^{3}$ Hachioji Laboratory, \\ SRL Inc., Komiya-cho, Hachioji, Tokyo 192-8535; ${ }^{4}$ Department of Laboratory Medicine, \\ Jikei University School of Medicine, Minato-ku, Tokyo 105-8461, Japan
}

Received February 26, 2017; Accepted April 10, 2017

DOI: $10.3892 /$ ijo.2017.3982

\begin{abstract}
It has been proposed that $\alpha$-fetoprotein (AFP) is a new member of the intracellular signaling molecule family of the phosphoinositide 3-kinase (PI3K)/AKT signaling pathway via interaction with the phosphatase and tensin homolog (PTEN). In this study, the effects of anti-human AFP antibody on the functions of PTEN were examined using an AFP-producing human hepatoma cell line. The antibody caused significant inhibition of cell growth, compared to a normal IgG control, with the accumulation of intracellular immune complexes followed by significant reduction of cytosolic functional AFP. Decrease in the amount of AKT phosphorylated on serine (S) 473 indicated that PI3K/AKT signaling was suppressed in the cells. S380-phosphorylated PTEN increased markedly by the second day after antibody treatment, with slight but significant increase in the PTEN protein level. Since phosphorylation at S380 is critical for PTEN stability, the increase in S380-phosphorylated PTEN indicated maintenance of the number of PTEN molecules and the related potential to control PI3K/AKT signaling. p53 protein (P53) significantly, but slightly increased during antibody treatment, because PTEN expression increased the stability and function of P53 via both molecular interactions. P53 phosphorylated at S20 or at S392 dramatically increased, suggesting an increase in the stability, accumulation and activation of P53. Glucose transporter 1 (GLUT1) increased immediately after antibody treatment, pointing to a deficiency of glucose in the cells. Immunofluorescence cytology revealed
\end{abstract}

Correspondence to: Professor Tadashi Asakura, Radioisotope Research Facilities, Research Center for Medical Science, Jikei University School of Medicine, 3-25-8 Nishi-Shinbashi, Minato-ku, Tokyo 105-8461, Japan

E-mail: tad_asakura@jikei.ac.jp

Key words: AFP, anti-AFP antibody, PTEN, hepatocellular carcinoma, anticancer sero-therapy that antibody-treatment re-distributed GLUT1 molecules throughout the cytoplasm with a reduction of their patchy localization on the cell surface. This suggested that translocation of GLUT1 depends on the PI3K/AKT pathway, in particular on PTEN expression. Antibody therapy targeted at AFP-producing tumor cells showed an inhibitory effect on the PI3K/AKT pathway via the liberation, restoration and functional stabilization of PTEN. PTEN simultaneously induced both P53 activation and intracellular translocation of GLUT1, since these are closely associated with PTEN.

\section{Introduction}

More than forty years ago, Mizejewski et al (1-4), Tsukada et al (5) and others (6-8) demonstrated in mouse, rat, and human cultured cell systems in vitro and mouse and rat experiments in vivo, that treatment with anti- $\alpha$-fetoprotein (AFP) serum or its purified antibody had a growth inhibitory effect on AFP-producing tumor cells, such as hepatocellular carcinoma and yolk sac tumor. Ohkawa et al focused on the finding that the administered anti-AFP antibody led to remarkable inhibition of sugar uptake by the neoplastic cells (8), suggesting that one of the main mechanisms of the antitumor effect of the antibody was impeding the transportation of nourishment across the cell membrane. However, most of the mechanisms of action of the antibody-derived antitumor effect remained obscure, because the main research focus shifted to the application of the specific antibodies as carriers of anticancer drugs or toxins in drug delivery systems (9-17). In addition, antibodymediated immuno-radioimaging experiments aimed at tumor diagnosis and/or therapeutic modalities using the antibody directed against tumor markers coupled to radioisotopes was promulgated $(7,18-23)$ and the mechanism of action underlying the antitumor effect of anti-AFP antibody was overlooked.

The possibility that AFP is a cell growth factor has been discussed recently (24-31), and its effect in promoting cell proliferation has been reported in a number of cell types. There have also been many reports that the cell growth-promoting effects of intracellular AFP are based on the close relationship with the phosphoinositide 3-kinase (PI3K)/AKT (known as 
protein kinase B) signaling pathway (30-36). Interactions of intracytoplasmic membrane-bound AFP with several kinds of intracellular functional and essential proteins have been also reviewed (31). These findings suggest that AFP must be a new member of the intracellular molecule family of the PI3K/AKT signaling pathway. It has been reported that AFP in the cell strongly interacts with the phosphatase and tensin homolog deleted on chromosome 10 (PTEN), which is a tumor suppressor molecule that strictly regulates PI3K/AKT signaling (30-36), and the interaction leads to a functional decline of PTEN. As a result, the PI3K/AKT signaling pathway might be activated as a tumor survival system. Conversely, experiments on the suppression of AFP protein expression using the RNA interference technology or microRNA network demonstrated that a severe decrease in AFP within the cell liberated intracellular PTEN molecules from the cytoplasmic AFP molecules, and led to restoration of the phosphatase-dependent and/or -independent activities with a regulatory function to the PI3K/ AKT signaling pathway (32-34). Innovative research with a breakthrough result was recently reported and entailed adding a novel antibody with single-chain variable fragment ( $\mathrm{scFv}$ ) to AFP, thereby blocking AFP and inhibiting hepatoma cell growth via the PI3K/AKT/PTEN signaling pathway (37). However, possible inhibitory mechanism of action of anti-AFP antibody against tumor cell growth did remain obscure in the report.

In the present experiments, to determine the antitumor efficacy of the antibody, the effect of antibody against human AFP on the AFP denaturation and/or degradation caused by antigen-antibody immune reactions, as well as on the biological behavior of PTEN molecules and on the PI3K/AKT signaling pathway were investigated using the AFP-producing human hepatocellular carcinoma cell line, FLC7. FLC7 cells are able to grow in chemically defined synthetic medium without any addition of peptide growth factors or animal proteins. Use of this cell line in the study is convenient and essential in order to determine the effects on cells of an antibody under a culture environment in which the trace effects of known and unknown growth-related materials are absent. This study was conducted to elucidate part of the mechanism underlying the antitumor effect of anti-AFP antibody.

\section{Materials and methods}

Cell culture. The FLC7 cell line (previously known as JHH-7), initially established from Japanese patient with hepatocellular carcinoma (38), has been adapted to grow under serum-free condition with differentiated liver functions. In brief, FLC7 cells were initially cultivated in ASF104N medium (Ajinomoto Healthy Supply Co., Inc., Tokyo, Japan), which is a chemically defined serum-free medium containing only recombinant human transferrin and insulin as growth factors. Then the media were replaced with chemically defined completely synthetic media (IS-RPMI, RPMI-1640, $5 \mathrm{mM}$ HEPES, $3 \times 10^{-8} \mathrm{M} \mathrm{Na}_{2} \mathrm{SeO}_{3}, 1 \times 10^{-8} \mathrm{M} \mathrm{NH}_{4} \mathrm{VO}_{3}, 3 \times 10^{-9} \mathrm{M}$ $\left(\mathrm{NH}_{4}\right)_{6} \mathrm{Mo}_{7} \mathrm{O}_{24}-4 \mathrm{H}_{2} \mathrm{O}, 1 \times 10^{-7} \mathrm{M} \mathrm{FeSO}_{4}-7 \mathrm{H}_{2} \mathrm{O}, 3 \times 10^{-9} \mathrm{M}$ linoleic acid, $3 \times 10^{-9} \mathrm{M}$ oleic acid and $1.55 \times 10^{-2} \mathrm{M} \mathrm{NaHCO}_{3}$ ) without any addition of peptides or animal materials (39) and then the cells were continuously cultivated under the conventional culture conditions in a $\mathrm{CO}_{2}$ incubator. The spent culture media of IS-RPMI (CM) of FLC7 cells culturing were stocked as supplement for sub-culture. FLC7 cells were routinely plated and sub-cultured with 50\% CM-containing IS-RPMI and the media were replaced with fresh IS-RPMI after 2 days of culture.

Cytotoxicity. FLC7 cells $\left(5 \times 10^{4}\right)$ were initially cultured in 24-well culture plates (Greiner Bio-One, Tokyo, Japan) with $1 \mathrm{ml}$ of IS-RPMI containing $0.5 \%$ of ASF104N, instead of $\mathrm{CM}$ in which AFP and other growth factor related various materials with known and unknown types were probably contained. After $12 \mathrm{~h}$ of culture, the cells, attached to the plates, were twice washed with $2 \mathrm{ml}$ of warmed IS-RPMI and then media were replaced completely with $1 \mathrm{ml}$ of fresh warmed IS-RPMI, which contained various concentrations of rabbit immunoglobulin (Ig) G of anti-human AFP antibody or rabbit pre-immune (normal) IgG. The cells were cultured continuously for $96 \mathrm{~h}$ with each IgG. After the incubation, viable cells were determined with the colorimetric assay using WST-8 (Cell Counting kit-8, Dojindo Lab., Kumamoto, Japan) and the results were expressed by the following equation: survival rate $(\%)=100 \mathrm{x}$ (absorbance at $450 \mathrm{~nm}$ of the each IgG-exposed cells) / (absorbance at $450 \mathrm{~nm}$ of the non-treated control cells). Additionally another type of cytotoxic assay was also carried out using each rabbit anti-human AFP antibody IgG or rabbit normal IgG at the concentration of the $50 \%$ growth inhibitory concentration value $\left(\mathrm{IC}_{50}\right)$, determined with the above results. In brief, to determine the $\mathrm{IC}_{50}$ in this assay, the cell viability assessed by WST- 8 was expressed as the fraction of surviving cells in anti-human AFP antibody IgG-treated cells relative to those in the normal IgG-treated controls, instead of IgG non-treated cells and the $\mathrm{IC}_{50}$ was calculated. At the concentration of $\mathrm{IC}_{50}$, the cells were cultured for indicated periods of time in the IS-RPMI. Results were calculated as mean \pm SD of triplicate determinations of two independent experiments.

Cell lysate. Either rabbit anti-human AFP antibody IgG- or rabbit normal IgG-treated cultured cells with various time intervals and concentrations were rapidly washed twice with $2 \mathrm{ml}$ of ice-cold Dulbecco's PBS (-) in wells, then added $200 \mu \mathrm{l}$ of ice-cold cell lysis buffer (50 mM Tris- $\mathrm{HCl}, \mathrm{pH} 7.5,0.15 \mathrm{M}$ $\mathrm{NaCl}, 1 \mathrm{mM}$ EDTA, $0.1 \%$ sodium dodecyl sulfate (SDS), $1 \mathrm{mM}$ phenylmethylsulphonyl fluoride, $1 \%$ Triton $\mathrm{X}-100$, $1 \%$ deoxycholate, $1 \mathrm{mM} \mathrm{Na}_{3} \mathrm{VO}_{4}, 1 \mathrm{mM} \mathrm{NaF}, 0.02 \% \mathrm{NaN}_{3}$ and protease inhibitor cocktail and phosphatase inhibitor cocktail 2 and 3 (Sigma-Aldrich Japan, Tokyo, Japan). After incubation for $20 \mathrm{~min}$ on ice, collected lysates were centrifuged at $23,000 \mathrm{x} \mathrm{g}$ for $20 \mathrm{~min}$ at $4^{\circ} \mathrm{C}$. The supernatants were kept frozen at $-80^{\circ} \mathrm{C}$ until use. The protein concentration was measured by the DC protein assay kit (Bio-Rad, Richmond, CA, USA). Bovine serum albumin (BSA) was used as the standard.

AFP-enzyme-linked immunosorbent assay (ELISA). AFP concentrations in the cultured media and the cell lysates were determined using the sandwich ELISA system (AFP ELISA kit; Abnova, Taipei, Taiwan), according to the manufacturer's instructions. Intracellular AFP concentrations were expressed as (ng)/(mg of cell lysate). Data were expressed as mean \pm SD of two independent experiments. 
SDS polyacrylamide gel electrophoresis/immunoblotting (SDS-PAGE/WB). After SDS-PAGE/WB, the polyvinylidene fluoride filters (Abcam, Tokyo, Japan) were blocked and then incubated with the corresponding primary antibodies, followed by horseradish peroxidase (HRP)-labeled second antibodies directed against rabbit, mouse, or goat $\operatorname{IgG}$ (Abcam), as described previously (40). Enhanced chemiluminescence (ECL) signals (ImmunoStar, Wako Pure Chemical Industries, Ltd., Tokyo, Japan) were detected by a cooled CCD camera system (ATTO light-capture II type AE-6981; ATTO Co., Tokyo, Japan). Primary antibodies used were AKT, AKT phosphorylated at serine (S) 473 (pAKT), p53 protein (P53) phosphorylated at S20 (pP53S20), MDM2 phosphorylated at S166 (pMDM2) (Cell Signaling Technology Inc., Tokyo, Japan), extracellular signal regulated kinase 1/2 (ERK1/2), PTEN, $\beta$-catenin (BD Biosciences, Tokyo, Japan), ERK1/2 diphosphorylated at T183 and Y185 (pERK1/2), $\beta$-actin, $\alpha$-tubulin (Sigma-Aldrich Japan), PTEN phosphorylated at S380 (pPTEN), glycogen synthase kinase $3 \beta$ phosphorylated at S9 (pGSK3 $\beta$ ), glucose transporter isoform 1 (GLUT1), P53, P53 phosphorylated at S392 (pP53S392), P53 phosphorylated at S46 (pP53S46) and AFP (Abcam). Densitometric analysis of bands was performed using ImageJ software (1.50i, NIH). Data were expressed in arbitrary units as average of at least three independent experiments. The data of densitometric analyses from all bands were corrected by densities of each $\alpha$-tubulin band, which was used as a loading control, and this provided the exact changes of the protein levels after antibody treatment. The data were calculated according to the following formula: the relative intensity $=$ (the band intensity of the indicated day) / (the band intensity at day 7 of rabbit normal IgG-treated cells, instead of IgG non-treated control cells at day 0 or day 7).

Dot blot analysis. Cell lysates prepared from cells treated with either rabbit normal IgG or anti-human AFP antibody IgG for 7 days at $50.0 \mu \mathrm{g} / \mathrm{ml}$ were spotted (each $1 \mu \mathrm{l}$ of $10,5,2.5$ and $1 \mu \mathrm{g} / \mu \mathrm{l}$ ) on nitrocellulose filters (Bio-Rad), dried and blocked. For detection of rabbit IgG, such as antibody administered and probably internalized in the cells, HRP-labeled goat anti-rabbit $\mathrm{IgG}$ was employed. For detection of intracellular AFP, the same above filters were used after procedure of de-probing the antibodies with signal stripping buffer (Restore ${ }^{\mathrm{TM}}$ PLUS Western Blot Stripping Buffer; Thermo Fisher Scientific Inc., Yokohama, Japan). After blocking, the filters were incubated with goat anti-human AFP antibody (Abcam) followed by HRP-labeled donkey anti-goat IgG (Abcam). Signals of each spot were obtained by ECL capture (ATTO light-capture II). Densitometric data were expressed as mean \pm SD of three independent experiments.

Immunofluorescence cytology of subcellular localization of GLUT1. FLC7 cells were cultured with media containing either rabbit normal IgG or rabbit anti-human AFP antibody $\mathrm{IgG}$, at $75 \mu \mathrm{g} / \mathrm{ml}$ concentration using a glass bottom culture dish (Iwaki Glass Base Dish, Asahi Glass Co., Ltd., Tokyo, Japan). After 5 days of culture, the cells were gently rinsed twice with cold Dulbecco's PBS (-), fixed with 3.3\% formaldehyde in Dulbecco's PBS (-) for $10 \mathrm{~min}$ at $4^{\circ} \mathrm{C}$. After rinsing with Dulbecco's PBS (-), the cells were permeabilized with
$0.1 \%$ Triton X-100 in Dulbecco's PBS (-) for $10 \mathrm{~min}$ at $4^{\circ} \mathrm{C}$ and then blocked with 5\% BSA and donkey normal $\mathrm{IgG}(5 \mathrm{mg} / \mathrm{ml})$ in Dulbecco's PBS (-) containing 0.1\% Tween-20 (TPBS) for $4 \mathrm{~h}$. The cells were incubated with goat anti-GLUT1 antibody (C-20; Santa Cruz Biotechnology, Inc., Dallas, TX, USA) diluted with 5\% BSA in TPBS for $17 \mathrm{~h}$ at $4^{\circ} \mathrm{C}$. After gentle washing, the cells were further incubated with Alexa Fluor $^{\circledR}$ 488-labeled donkey anti-goat IgG (Abcam) in 5\% BSA containing TPBS for $1 \mathrm{~h}$ at $37^{\circ} \mathrm{C}$. After rinsing with Dulbecco's PBS (-), immunofluorescence images were captured using a Keyence BZ-8000 microscope (Keyence Corp., Inc., Osaka, Japan).

Reagents. For investigation on cell growth inhibition tests, rabbit polyclonal anti-human AFP antibody IgG (\#PA-012) was obtained from Nippon Bio-Test Lab. Inc. (Tokyo, Japan). Rabbit normal IgG was purchased from Sigma-Aldrich Japan. For cell treatments, both IgG solutions were extensively dialyzed against Dulbecco's PBS (-) followed by IS-RPMI at $4^{\circ} \mathrm{C}$. The solutions were filter-sterilized before use. BSA and donkey normal serum were from Sigma-Aldrich Japan. Donkey normal IgG fraction was prepared from its normal serum by the salting out method using $33 \%$ ammonium sulfate, followed by dialyzed extensively against $0.9 \% \mathrm{NaCl}$ at $4^{\circ} \mathrm{C}$. Protein concentration was measured by the $\mathrm{DC}$ protein assay kit (Bio-Rad) using the bovine serum IgG as the standard. RPMI-1640 medium was from Nissui Pharmaceutical Co., Ltd. (Tokyo, Japan). All other chemicals were of reagent grade.

Statistical analysis. Values of $\mathrm{p}<0.05$ were considered statistically significant using Fisher's exact test.

\section{Results and Discussion}

Growth inhibition by anti-AFP antibody. Continuous exposure of the cells for $96 \mathrm{~h}$ to rabbit anti-human AFP antibody dose-dependently inhibited cell growth of the human hepatocellular carcinoma FLC7, as compared with the normal IgG control (Fig. 1A). The concentration of IgG of anti-human AFP antibody at $\mathrm{IC}_{50}$ was calculated to be $\sim 50.0 \mu \mathrm{g} / \mathrm{ml}$. As a result of treating cells for up to 7 days with rabbit anti-human AFP antibody at the concentration of $50.0 \mu \mathrm{g} / \mathrm{ml}$, the antibody exhibited significant and time-dependent growth inhibition compared to the rabbit normal IgG used as the control (Fig. 1B).

Possibility of the formation of immune complexes. ELISAdetermination of AFP showed that addition of anti-human AFP antibody decreased the AFP concentration in the medium below the detection limit (data not shown). At the same time, anti-human AFP antibody significantly reduced intracellular AFP levels up to $3.67-15.7 \%$ of the AFP concentration in rabbit normal IgG-treated control cells (Fig. 2A). Interestingly, however, SDS-PAGE/WB analysis of cell lysates using a goat antibody against human AFP and an HRP-labeled donkey antigoat IgG antibody without cross-reactions to rabbit IgG revealed that the amount of AFP in the anti-AFP antibody-treated cells did not decrease substantially compared with that in IgG-treated control cells (Fig. 2B and C). Additionally, by anti-AFP antibody treatment of the cells, three detectable immunoreactive bands 
A

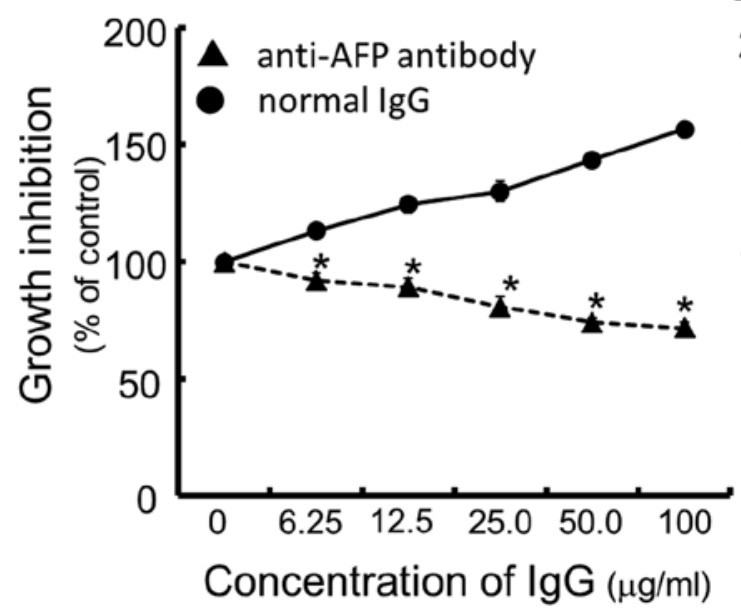

B

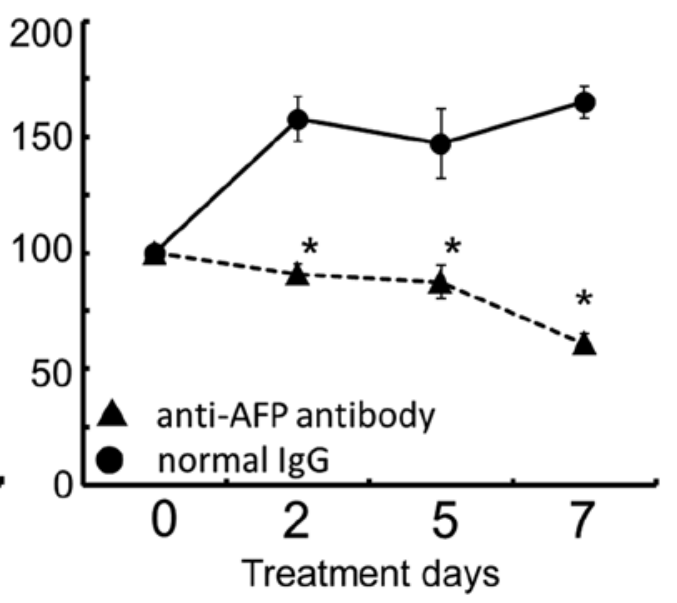

Figure 1. Growth inhibition of anti-AFP antibody. (A) Cells were continuously treated with either rabbit anti-AFP antibody IgG or rabbit normal IgG at various concentrations for $96 \mathrm{~h}$. (B) Cells were treated with either rabbit anti-AFP antibody IgG or rabbit normal $\mathrm{IgG}$ at the $\mathrm{IC}_{50}$ concentration of $50.0 \mu \mathrm{g} / \mathrm{ml}$ for the indicated periods of time. Viable cell numbers were examined by the WST-8 colorimetric assay. Details are seen in Materials and methods. Points, means of triplicate determinations of two independent examinations; bars, SD (indicated unless smaller than the point as plotted). ${ }^{*}$ Significant difference $(\mathrm{p}<0.05$ ) compared to rabbit normal IgG-treated cells.

A

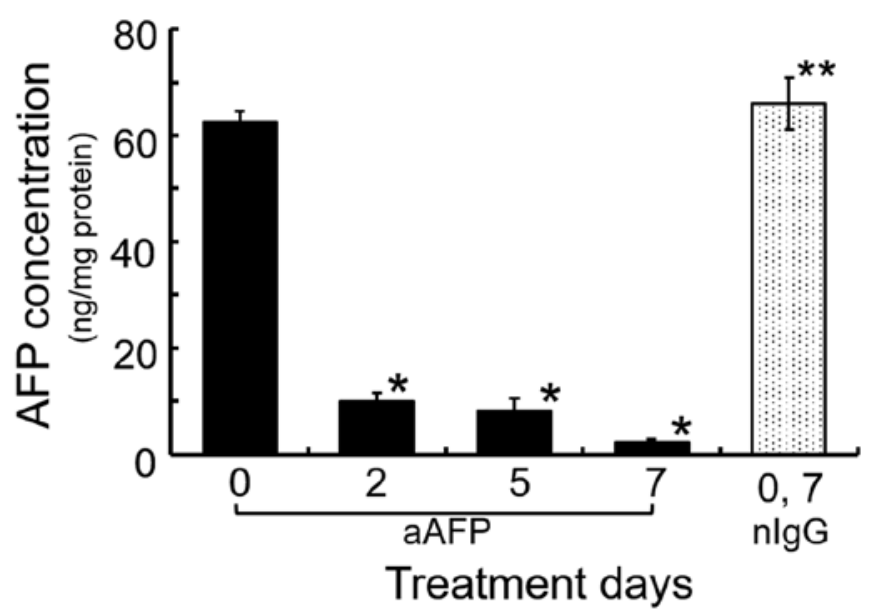

C

a

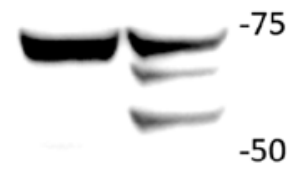

$-37$

b

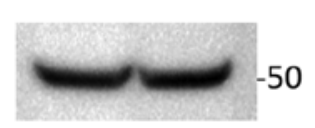

B

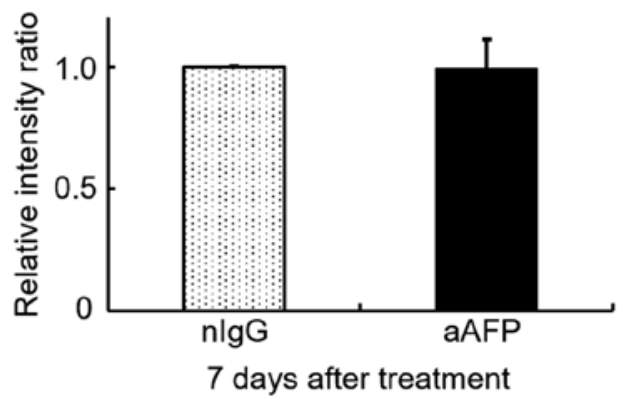

D

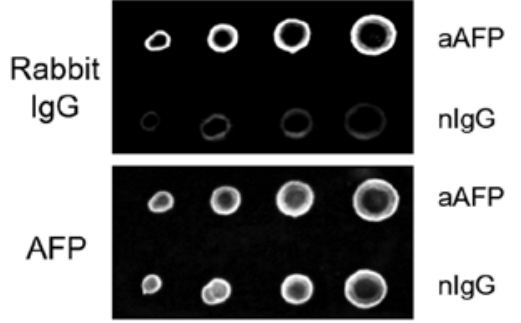

Figure 2. Reduction of intracellular functional AFP concentration. Cells were treated with either rabbit anti-AFP antibody IgG (aAFP) or rabbit normal IgG (nIgG) at $50.0 \mu \mathrm{g} / \mathrm{ml}$ for 7 days. Cell lysates were prepared. (A) AFP concentration was assayed with ELISA. Columns, mean of triplicate determinations of two independent examinations; bars, SD. nIgG, mean \pm SD of six selected samples obtained from cells treated with rabbit normal IgG on days 0 and 7 . * Significant difference $(\mathrm{p}<0.05)$ compared to cells treated with rabbit either aAFP at day 0 or nIgG at days 0 and 7 . $^{* *}$ Non-significant difference $(\mathrm{p}>0.05)$ compared to cells treated with aAFP at day 0. Details are seen in Materials and methods. (B) Detection of anti-AFP antibody-reactive bands using SDS-PAGE/WB. Densitometric intensities of bands were analyzed by NIH ImageJ software and were corrected by densities of each $\alpha$-tubulin band. The data were calculated according to the following formula: the relative intensity (ratio) $=$ (the band intensity of the indicated day) / (the band intensity of the nIgG-treated cells on day 7). Details are seen in Materials and methods. (C) Typical SDS-PAGE/WB pattern of intracellular anti-AFP antibody reactive bands (a) and $\alpha$-tubulin (b). (D) Dot reactivities of cell lysates to anti-AFP antibody (AFP), or anti-rabbit IgG antibody (rabbit IgG). Immunoreactivities were determined in the lysates from cells treated with either aAFP or nIgG for 7 days at $50.0 \mu \mathrm{g} / \mathrm{ml}$, using ECL-densitometric analyses. Details are seen in Materials and methods. 
Table I. Increased densitometric intensities of intracellular rabbit IgG-immunoreactivity in cell lysates treated with rabbit anti-AFP antibody IgG (dot blot analysis).

Integrated density

\begin{tabular}{|c|c|c|c|c|c|}
\hline \multirow[b]{3}{*}{ Antibody to } & \multirow[b]{3}{*}{ Cell lysate $(\mu \mathrm{g})$} & \multirow{2}{*}{\multicolumn{2}{|c|}{ aAFP-treated cells }} & & \\
\hline & & & & \multicolumn{2}{|c|}{ nIgG-treated cells } \\
\hline & & Mean & SD & Mean & $\mathrm{SD}$ \\
\hline \multirow[t]{4}{*}{ Rabbit IgG } & 10 & $205936^{\mathrm{a}}$ & 34735.3 & 67785.7 & 28598.6 \\
\hline & 5 & $142118^{\mathrm{a}}$ & 31881.8 & 51623.7 & 17121.1 \\
\hline & 2.5 & $101126^{\mathrm{a}}$ & 13536.7 & 44261.0 & 20816.0 \\
\hline & 1 & $63133.7^{\mathrm{a}}$ & 30589.2 & 18683.3 & 7903.6 \\
\hline \multirow[t]{4}{*}{ AFP } & 10 & 408798 & 51751.8 & 341240 & 58997.5 \\
\hline & 5 & 315853 & 52217.1 & 291631 & 49265.0 \\
\hline & 2.5 & 237805 & 31213.6 & 221156 & 50002.1 \\
\hline & 1 & 145434 & 49046.1 & 123246 & 40601.6 \\
\hline
\end{tabular}

${ }^{a}$ Significantly higher $(\mathrm{p}<0.05)$ density compared to lysate from cells treated with normal rabbit $\operatorname{IgG}(\mathrm{nIgG})$. Details are seen in Materials and methods. aAFP, rabbit anti-AFP antibody IgG.

were found and they might be degradation products of the AFP molecules. Typical result is shown in Fig. 2C. Dot blot analyses demonstrated that the presence of anti-rabbit IgG specific immunoreactive substances, presumably derived from administered rabbit anti-AFP antibody to the cells, was sufficiently detectable with higher significance compared to normal IgG-administered cells (Fig. 2D and Table I). By contrast, the AFP reactive densitometric signals in both cell lysates were nearly the same. In each concentration of cell lysates applied on nitrocellulose filters, rabbit IgG derived signals were 2.4-3.4 times higher in the anti-AFP antibody-treated cell lysates as compared to normal IgG-treated corresponding cell lysates (Table I). In these results, treatment of the cells with anti-AFP antibody might have led to the presence of free antibody due to an excess of antibody and the presence of immune complex (IC) generated from the administered antibody and AFP in the cell. When intracellular AFP is measured by an immunochemical technique such as ELISA, it can be predicted that both the excess antibody and the IC competitively inhibit the assay system. Analysis of the amount of intracellular AFP molecules by two different methods showed an obvious discrepancy between the results of each method, pointing to the generation and accumulation of IC in the cells. These results suggest that the amount of AFP was not reduced in antibody-treated cells, but rather, the reaction products of AFP and polyclonal anti-AFP antibody administered, the so-called ICs, had accumulated. Generation and accumulation of ICs consisting of multimeric aggregates of antibody and AFP is expected to inhibit AFP function without a large fluctuation in the amount of intracellular AFP. In other words, a large amount of AFP exists in the cytoplasm, but it is possible that its functions have been lost. As shown for the first time in this experiment the existence of intracellular IC derived from the antibody added extracellularly is sufficiently suspected.

Intracellular uptake of $\mathrm{IgG}$ molecules such as antibodies is known to occur by pinocytosis, macropinocytosis or endocytosis across the cell membrane. However, the mechanism for maintaining the function of antibody internalized in the cytoplasm is not well known (41-43). In recent years, McEwan et al and Watkinson et al and their co-workers proposed the concept of intracellular antibody immunity $(44,45)$ and many investigators reported methods for screening cell-internalizing antibodies, which possess high cell-internalizing activity, from polyclonal antibodies $(46,47)$. It is possible that the cell-internalized antibody exerts its own unique function in the cell. Accordingly, there are many unknown factors to elucidate in this interesting field.

It is well-known that the cell growth promoting effect of AFP is exerted by interaction with many other molecules (32-37). Furthermore, in principle, intermolecular interaction is based on the three-dimensional structure of related molecules. As a result of antibody binding followed by IC generation, it is highly possible that AFP molecules with a conformational change may lose their ability to interact with other related molecules and become so-called non-functional AFP. Even though abundant non-functional AFP is present in the cell, AFP functions such as growth promotion must be suppressed. Conversely, it is reasonable to infer that the intracellular AFP concentration measured by ELISA may correspond to the amount of AFP, which is not affected by IC generation and remains functional. Based on these results, it can be deduced that most of the AFP molecules detected by SDS-PAGE/WB in antibody-treated cells are non-functional AFP, and the cellular environment resulting from anti-AFP antibody treatment in this study was very similar to the environment of intracellular AFP elimination caused by experiments on RNA interference and microRNA technology, as reported previously (32-34,37). Therefore, we confirmed the importance of further analyzing the changes in some major molecules interacting with the AFP molecule in the cell induced by anti-AFP antibody treatment.

Additionally in this experiment, the amount of AFP in the antibody-treated cells fluctuated slightly (Fig. 2B). The 
A

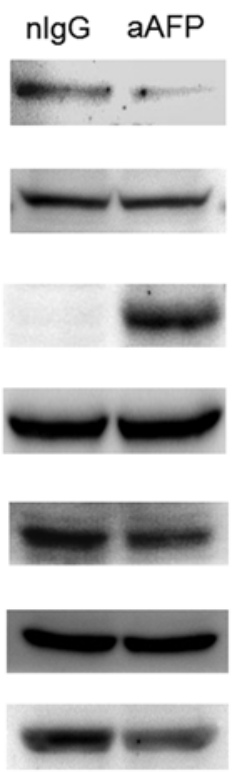

nlgG aAFP

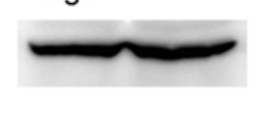

AKT

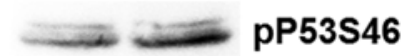

PPTEN

S380

PTEN

PERK

ERK

pGSK3 $\beta$

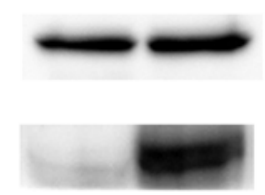

P53

pMDM2

\section{$\beta$-catenin}

$\beta$-actin

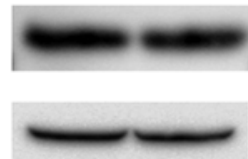

B

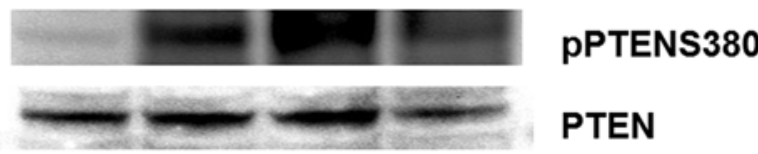

PTEN

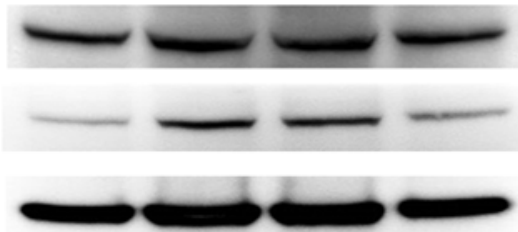

GLUT1

pP53S20

pP53S392

\section{P53}

pMDM2

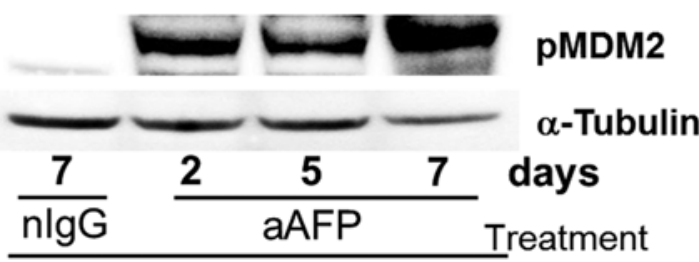

C
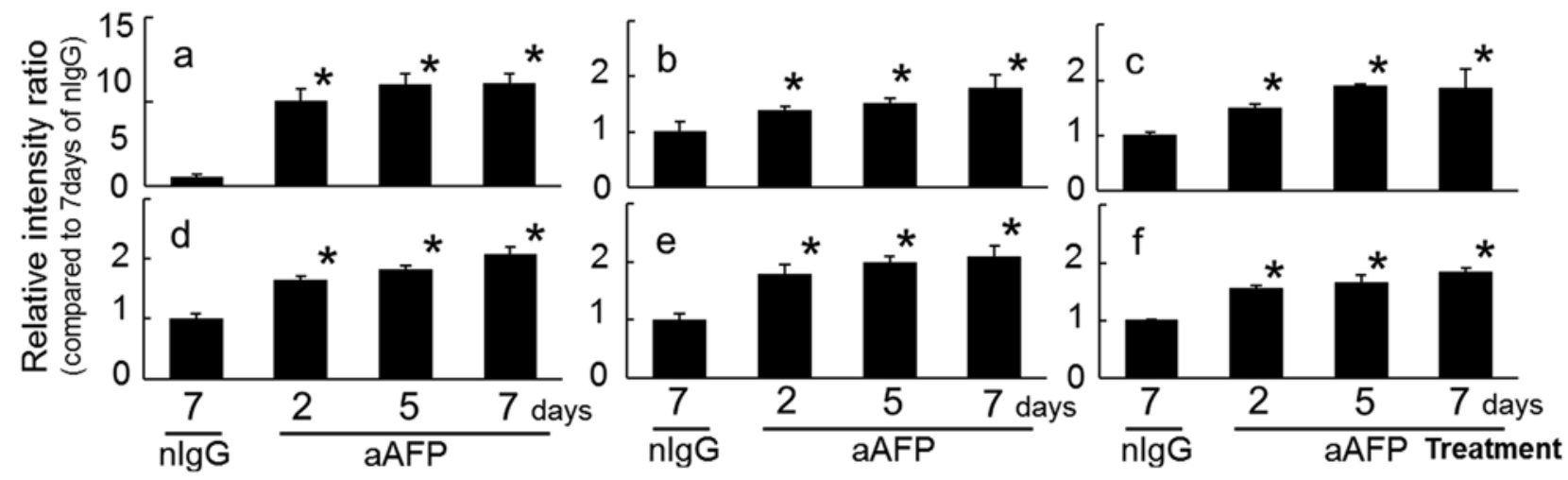

Figure 3. Changes in some key proteins after treatment with antibody. (A) Cells treated with $50.0 \mu \mathrm{g} / \mathrm{ml}$ of either rabbit anti-AFP antibody IgG (aAFP) or rabbit normal IgG (nIgG) for 7 days were washed and lyzed, and the resultant lysates were examined using SDS-PAGE/WB. (B) Cells treated with $50.0 \mu \mathrm{g} / \mathrm{ml}$ of either rabbit anti-AFP antibody IgG or rabbit normal IgG for the indicated periods of time were washed and lyzed, and the prepared lysates were examined using SDS-PAGE/WB. (C) Densitometric intensities of bands were analyzed and corrected by densities of each $\alpha$-tubulin band, like the determination of AFP bands. a, PTENS380; b, PTEN; c, GLUT1; d, P53; e, P53S20; f, P53S392. Details are seen in Materials and methods. "p<0.05 compared to nIgG-treated control at day 7 .

possible cause of this variation is considered to be the result of intracellular degradation of AFP derived from ICs, based on the anti-AFP antibody reactive bands in the low molecular weight region recognized by SDS-PAGE/WB analysis of the cell lysate treated with anti-AFP antibody (Fig. 2C). It is also another possibility on AFP-fragmentation that anti-AFP antibody in the cytoplasm binds to fragments of AFP molecule on messenger RNA being translated at the ribosomes, as reported in the purification experiment for messenger RNA of AFP by Miura et al (48). If this phenomenon occurs in the cell, it can be predicted that AFP protein synthesis would be inhibited and the protein fragments with incomplete length would be generated.

Anti-AFP antibody-induced suppression of the PI3K/AKT pathway via PTEN stabilization. In this study, phosphorylation on S473 of the AKT molecule which is the protagonist of the PI3K/AKT signaling pathway was reduced by anti-human AFP antibody treatment (Fig. 3A). This result indicated that the PI3K/AKT signaling pathway was suppressed in anti-AFP antibody-treated FLC7 cells. It has been reported that in AFP-producing tumor cells, intracellular AFP molecules bind and interact closely with PTEN molecules, thereby suppressing the PTEN functions (both phosphatase-dependent and -independent activities) and consequently upregulating the PI3K/AKT signaling pathway (30,32-35). Interestingly, the phosphorylated PTEN molecules at S380 were increased markedly by antibody treatment, with an extremely slight but significant variation in the intracellular protein level of PTEN (Fig. 3). At the same time, phosphorylation of ERK1/2 (T183 and Y185) was also reduced, suggesting an inhibition state of the MAP kinase signaling systems in the cells (Fig. 3A). There have been some reports that each PTEN molecule, which localizes in the nucleus or cytoplasm, exhibited different effects on various signaling pathways (49-53). According to these reports, PTEN localizing in the cytoplasm decreases the level of phosphorylated AKT, upregulates $\mathrm{P} 27^{\mathrm{kip} 1}$ and is required for apoptosis, whereas PTEN localizing in the nucleus downregulates phosphorylated MAP kinase and cyclin D1 and is crucial for cell cycle arrest, respectively. A 

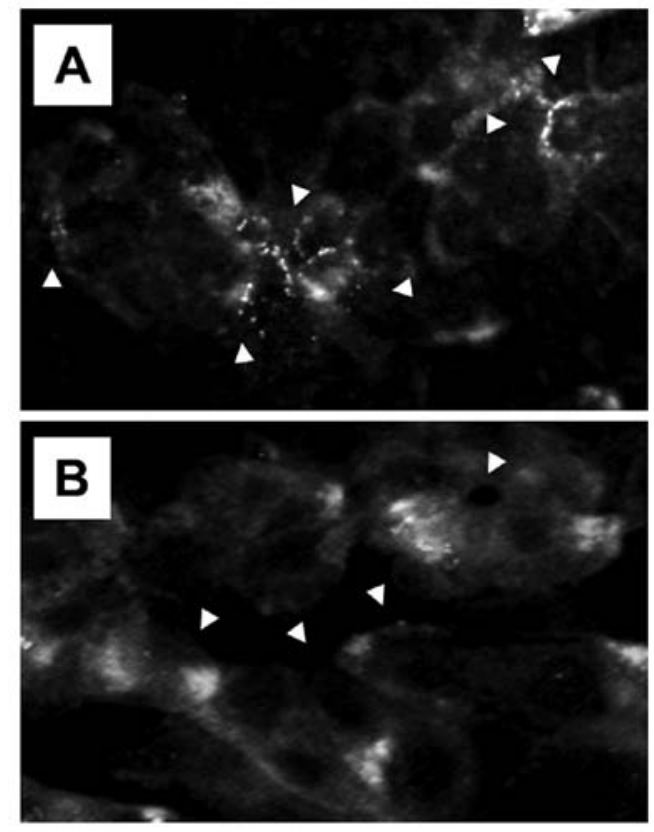

Figure 4. Subcellular distribution of GLUT1. Cells were treated with $75.0 \mu \mathrm{g} / \mathrm{ml}$ of either rabbit normal IgG (A) or rabbit anti-AFP antibody $\operatorname{IgG}$ (B) for 5 days in the glass based microchamber. After gentle washing, the fixed cells were stained with anti-GLUT1 antibody followed by Alexa Fluor 488-labeled second antibody and examined under fluorescence microscopy. GLUT1 immunoreactivities indicated by arrowheads. Original magnification, $\mathrm{x} 400$. Details are seen in Materials and methods.

recent study demonstrated that the anti-proliferative effect of synthetic anti-AFP scFv antibody on hepatic tumor cells was based on induction of G1 cell cycle arrest and apoptosis, probably related to the PI3K/AKT/PTEN signaling network (37), but a possible mechanism of action of anti-AFP $\mathrm{scFv}$ on cell-growth inhibition was not discussed in their report. As a result, the PTEN molecule can be expected to participate in the mechanism underlying the antitumor effect manifested by anti-AFP antibody.

PTEN was modified through strong phosphorylation at S380 of the carboxyl-terminal region (C-terminal tail domain) on the second day and thereafter due to antibody treatment. Phosphorylation of the S380, S385, T382, and T383 residues, but not T366, in the C-terminal region of PTEN molecules is known to not only increase the stability of the PTEN molecule but also decrease its phosphatase activity (54-60). The C-terminal tail domain of PTEN has been shown to be important in regulating the stability and half-life of the molecules. Specifically, it is known that phosphorylation of the $\mathrm{S} 380$ residue is critical for PTEN protein stability (61-64). Phosphorylation on S380 of PTEN at an early stage after antibody administration indicated that molecular stability was improved, but, on the other hand, excessive phosphatase activity was somewhat inhibited. It is thought that this phenomenon may be related to maintaining the molecular numbers of PTEN and to sustaining the potential for PTEN to control the PI3K/AKT signaling pathway. However, further investigations are necessary to clarify the true action mechanism(s) of each PTEN molecule with phosphorylation at various target residues, because neither change in PI3K enzyme activity nor exact contents of phosphatidylinositol3,4,5-triphosphate was determined in this study.
As a result of adecrease in phosphorylated AKT(S473), phosphorylation on S9 of the GSK3 $\beta$ molecule, which is one of the target molecules of AKT (65), was relatively reduced (Fig. 3A). Conversely, enhancement of kinase activity of GSK $3 \beta$ is probable. Participation of GSK $3 \beta$ in PTEN-phosphorylation is already well recognized $(54,55,58,65,66)$, and it is thought that an increase in kinase activities of GSK $3 \beta$ might enhance phosphorylation at T366 on the target PTEN molecules (58). T366 phosphorylation promotes destabilization and degradation of PTEN molecules as reported previously $(58,67)$. However, in the present study, PTEN protein levels did show gradual and significant increase during treatment for up to 7 days (Fig. 3B and C). Due to the failure of molecular co-localization and interaction between AFP and PTEN occurring in the cytoplasm of the AFP-producing tumor cells, acute and severe reduction of the intracellular functional, immunoreactive AFP concentration due to IC generation caused by the administration of anti-AFP antibody resulted in a massive release of free and probably functional PTEN molecules from AFP in the cytoplasm. Moreover, intracellular protein levels of PTEN after antibody administration in this experiment were elevated slightly but significantly as shown in Fig. 3B and C. This finding suggests that selective phosphorylation on S380 of the free PTEN molecules induced molecular stabilization with the suppression of enzyme activity, as a mechanism to maintain potential control of the PI3K/AKT signaling pathway without degrading the rapidly increased level of PTEN molecules in the cell. To the contrary, this reaction should maintain the cancer cell property of preferential growth as a cancer cell inactivates excess PTEN molecules, which act as a major suppressive regulator in the PI3K/AKT signaling pathway and are, therefore, an impediment to proliferation reactions of the cancer cells. This mechanism is a self-defense reaction that usually occurs in cancer cells in order to survive. This is an interesting phenomenon in cancer biology and requires further elucidation. It has been reported that phosphorylation at S380 of the PTEN molecule at the C-terminal tail, does not involve casein kinase 2 and GSK3 $\beta$ (58-60), but a result of the interaction of other proteins, such as protein interacting with carboxyl terminus-1 (PICT-1) $(63,64)$. Okahara et al suggested that PICT-1 is a PTEN-interacting protein that promotes the phosphorylation and stability of PTEN, and can regulate the phosphorylation of PTEN at S380 $(63,64)$. The authors concluded that the binding of PTEN to PICT-1 governs its turnover via phosphorylation of the C-terminal region. Their result and the findings of our present study provide insight into unknown other molecular mechanism(s) by which PTEN turnover is controlled.

Upregulation of P53 functions by anti-AFP antibody treatment. Protein levels of P53 were slightly and significantly increased during antibody treatment (Fig. 3), because PTEN increased P53 stability and function via interaction of both molecules, which bind the $\mathrm{C} 2$ domain of PTEN to the C-terminus of P53 $(68,69)$. Therefore, in cells lacking PTEN, P53 levels are significantly reduced owing to decreased stability as reported previously (68). Expression of wild-type or phosphatase-dead forms of PTEN with a recombinant construct also increases P53 stability in MDM2 (a ubiquitin ligase for P53)-independent manner (68). Phosphorylation 
reactions of P53 on S20 and on S392 were significantly enhanced after antibody treatment (Fig. 3), suggesting stabilization and activation of the molecule. Post translational modifications of the P53 molecule, such as phosphorylation, acetylation, and ubiquitination, have been recognized to regulate the stability and functions of P53 proteins (69-74). It is well-known that DNA damage-induced phosphorylation at S20 of P53 leads to a reduced interaction between P53 and its negative regulator, MDM2. As a result, S20 phosphorylation impairs the ability of MDM2 to bind P53, promoting both accumulation and functional activation of P53 in response to DNA damage (72). MDM2 plays a central role in regulating the stability of P53 and inhibits P53 accumulation by targeting it for ubiquitination and proteasomal degradation (75-77). Phosphorylated P53 at S392 is also essential for promoting its tetramerization, stability, and functional activity as well as for S20-phosphorylation reactions (70,71). These findings indicate that the regular functions of P53 recovered after antibody treatment. Phosphorylation of P53 at S46, which regulates the ability of P53 to induce apoptosis (73), also increased slightly, suggesting the triggering of apoptotic signaling (Fig. 3A).

It is of interest that an extreme and significant increase in phosphorylated MDM2 on S166 (pMDM2) was observed in antibody-treated tumor cells within 2 days after the beginning of antibody administration (Fig. 3). As known previously $(76,77)$, the presence of pMDM2 indicates the enhancement of E3 ligase activity to promote ubiquitin-dependent degradation of P53. Additionally, phosphorylation at S166 and at S186 of MDM2 has been shown to depend on AKT enzyme activity (76,77). In the present study, antibody administration elicited a decrease in intracellular AFP, releasing PTEN from AFP, followed by stabilization of the molecular functions of free PTEN. The resultant free but functional PTEN was able to suppress the PI3K/AKT signaling system, which also serves as a survival pathway in cancer cells. PTEN also promoted stabilization and expression of the biological functions of the P53 molecule that interacts with the PTEN molecule. Under such circumstances, it can be deduced that the accumulation and abnormal increase of pMDM2 (S166) in liver cancer cells are needed in order to maintain a steady state of the cancer cells and enhance the degradation of P53, the tumor suppressor molecule, even when AKT enzyme activity is inhibited. There was no difference in the expression level of $\beta$-catenin protein (Fig. 3A), a major protein of the Wnt/ $\beta$-catenin pathway, which is one of the important cell survival regulatory pathways involving the PI3K/AKT/GSK3 $\beta$ axis (66).

Induction of subcellular translocation of GLUT1 by anti-AFP antibody. In the present study, protein levels of a universal molecule in the glucose transporter species, GLUT1, showed a significant increase immediately after antibody treatment and continued for 7 days (Fig. 3). The increase in GLUT1 protein levels observed early during antibody treatment clearly pointed to a deficiency of and need for glucose in the tumor cells. It is known that a proliferating tumor cell vigorously consumes sugar, especially glucose, irrespective of the presence or absence of oxygen. The fact that the PTEN function in FLC7 cells with a high level of AFP production was strongly suppressed by the AFP is compatible with the above-mentioned results. Under the condition of malfunction of PTEN, immunofluorescence cytology revealed a change in the subcellular localization of GLUT1 molecules (Fig. 4). In control cells with malfunction of PTEN, treated with rabbit normal IgG, many GLUT1 molecules were localized patchily on the surface of the cell membrane. In contrast, in cells treated with rabbit antiAFP antibody IgG, the distribution of the weak fluorescence indicating GLUT1 was found throughout the cytoplasm, and localization of GLUT1 on the cell surface membranes was reduced. Morani et al reported that in genetically manipulated human thyroid cancer cell lines, the loss of PTEN expression was associated with increased expression of GLUT1 on the cell surface plasma membrane and enhanced the translocation of GLUT1 proteins onto the surface of plasma membrane from the cytoplasm (78). They concluded that the PTEN protein regulated plasma membrane expression of GLUT1 and that the loss of function of PTEN increased the probability of cancer detection by ${ }^{18} \mathrm{~F}$-fluorodeoxyglucose positron emission tomography or other glucose-based imaging diagnosis in a clinical setting. This result was similar to the reported finding that the plasma membrane translocation of GLUT1 was dependent on the PI3K/AKT signaling pathway (79-81). Immunocytohistologic studies have also shown that enhanced glucose uptake in cancer cells correlates with overexpression of GLUTs, especially of GLUT1 $(78,81)$. Our results fully supported the previous findings that the restored PTEN molecules liberated from AFP closely participated in the process of intracellular distribution of GLUT1. To clarify the relationship between PTEN function and the translocation of GLUT1, it may be important to investigate other unknown function(s) of the PTEN molecule involved in regulating subcellular migration of the target molecules. As reported previously in our study (8), the inhibition of glucose uptake by the treatment of AFP-producing rat hepatoma AH66 cells with horse anti-rat AFP antibody occurred within a few hours after the treatment. There was no remarkable change in the $\mathrm{K}_{\mathrm{m}}$ value in the kinetic analysis of the uptake, while a decrease in the $\mathrm{V}_{\max }$ was observed indicating that non-competitive inhibition was the main cause of glucose uptake failure. At that time, it was assumed that no qualitative change in the transport carrier occurred, but there was a quantitative change and a decrease in the number of unknown sugar transporters. Currently, one of the effective treatments of hepatocellular carcinoma in the clinical setting is inhibition of angiogenesis in liver cancer tissue to induce malnutrition, such as deficiency of sugar, other nutrients and oxygen (82-85). The induction of such malnutrition in cancer cells in the present study by administration of anti-AFP antibody is a significant finding.

There have been several reports that small but detectable amounts of autoantibodies against human AFP were produced by an unknown factor in vivo, including in the presence of cancer (86-90). Generation of autoantibodies to carcinoembryonic antigen (CEA) has been also reported in several kinds of cancers and the expression of these anti-CEA autoantibodies depleted the serum CEA antigen levels (91-94). It can be postulated that by a similar unknown mechanism, excess amounts of autoantibodies raised against AFP in the serum or in the cells are generated, and then bind to AFP, thereby decreasing the AFP concentration. However, there are no reports yet of any findings related to AFP that might compare 
with the rapid deletion of serum CEA due to increased expression of anti-CEA autoantibody. The phenomenon of anti-AFP antibody eliminating abundant functional AFP from the cytoplasm as well as from the extracellular matrices, with severe accumulation of ICs as a result of some unknown phenomenon cannot be expected for liver cancer cells. Liver cells, parenchymal and non-parenchymal interstitial cells, as well as liver cancer cells exhibit a confusing biological reaction in response to the cellular environment resulting from anti-AFP antibody treatment.

As shown in this study, the administration of anti-AFP antibody had an inhibitory effect on cell growth via suppression of the PI3K/AKT signaling pathway. Because of a decrease in intracellular functional AFP resulting from the generation of ICs consisting of AFP and anti-AFP antibody, the production and accumulation of ICs derived from the AFP-anti AFP antibody reaction exerted the same cell growth inhibitory effect as inhibition of intracellular AFP expression. Unfortunately, the cytotoxicity and antitumor efficacy of the specific antibody alone were weaker in comparison to so-called anticancer agents. However, a more recent report indicated that intracellular AFP expression is closely related to hepatocarcinogenesis, as well as liver cancer progression (95). For such reasons, elucidating the mechanism of action of cytotoxicity of anti-AFP antibody on AFP-producing tumor cells serves as a sound basis not only for use in combination with other effective liver cancer therapy but also for developing strategic measures for liver cancer prevention.

\section{Acknowledgements}

This study was supported in part by MEXT-Supported Program for the Strategic Research Foundation at Private Universities (2011-2015) from the Ministry of Education, Culture, Sports, Science and Technology.

\section{References}

1. Mizejewski GJ and Allen RP: Immunotherapeutic suppression in transplantable solid tumours. Nature 250: 50-52, 1974.

2. Mizejewski GJ, Young SR and Allen RP: $\alpha$ fetoprotein: Effect of heterologous antiserum on hepatoma cells in vitro. J Natl Cancer Inst 54: 1361-1367, 1975.

3. Mizejewski GJ and Allen RP: $\alpha$-fetoprotein: Studies of tumorassociated antigen cytotoxicity in mouse hepatoma BW7756. Clin Immunol Immunopathol 11: 307-317, 1978.

4. Mizejewski GJ and Dillon WR: Immunobiologic studies in hepatoma-bearing mice passively immunized to $\alpha$-fetoprotein. Arch Immunol Ther Exp (Warsz) 27: 655-662, 1979.

5. Tsukada Y, Mikuni M, Watabe H, Nishi S and Hirai H: Effect of anti-alpha-fetoprotein serum on some cultured tumor cells. Int J Cancer 13: 187-195, 1974

6. Wepsic HT, Tsukada Y, Takeichi N, Nishi S and Hirai H: Effect of horse antibody to rat alpha-fetoprotein upon the growth of AH-66 in Donryu rats. Int J Cancer 25: 655-661, 1980.

7. Koji T, Ishii N, Munehisa $T$, Kusumoto $Y$, Nakamura $S$, Tamenishi A, Hara A, Kobayashi K, Tsukada Y, Nishi S, et al: Localization of radioiodinated antibody to alpha-fetoprotein in hepatoma transplanted in rats and a case report of alpha-fetoprotein antibody treatment of a hepatoma patient. Cancer Res 40: 3013-3015, 1980.

8. Ohkawa K, Tsukada Y, Hibi N and Hirai H: The inhibitory effects of horse anti-rat AFP antiserum on the uptake of 2-deoxyD-glucose by AFP-producing rat hepatoma cells. Int J Cancer 33: 497-502, 1984
9. Tsukada Y, Bischof WK, Hibi N, Hirai H, Hurwitz E and Sela M: Effect of a conjugate of daunomycin and antibodies to rat alpha-fetoprotein on the growth of alpha-fetoprotein-producing tumor cells. Proc Natl Acad Sci USA 79: 621-625, 1982.

10. Tsukada Y, Kato Y, Umemoto N, Takeda Y, Hara T and Hirai H: An anti-alpha-fetoprotein antibody-daunorubicin conjugate with a novel poly-L-glutamic acid derivative as intermediate drug carrier. J Natl Cancer Inst 73: 721-729, 1984.

11. Tsukada Y, Hurwitz E, Kashi R, Sela M, Hibi N, Hara A and Hirai $\mathrm{H}$ : Chemotherapy by intravenous administration of conjugates of daunomycin with monoclonal and conventional anti-rat alpha-fetoprotein antibodies. Proc Natl Acad Sci USA 79: 7896-7899, 1982.

12. Tsukada Y, Hurwitz E, Kashi R, Sela M, Hibi N, Hara A and Hirai H: Effect of a conjugate of daunomycin and purified polyclonal or monoclonal antibodies to rat alpha-fetoprotein on the growth of alpha-fetoprotein-producing tumor cells. Ann NY Acad Sci 417: 262-269, 1983.

13. Kato Y, Tsukada Y, Hara T and Hirai H: Enhanced antitumor activity of mitomycin $\mathrm{C}$ conjugated with anti-alpha-fetoprotein antibody by a novel method of conjugation. J Appl Biochem 5: 313-319, 1983.

14. Tsukada Y, Ohkawa K and Hibi N: Suppression of human alphafoetoprotein-producing hepatocellular carcinoma growth in nude mice by an anti alpha-foetoprotein antibody-daunorubicin conjugate with a poly-L-glutamic acid derivative as intermediate drug carrier. Br J Cancer 52: 111-116, 1985.

15. Ohkawa K, Hibi N and Tsukada Y: Evaluation of a conjugate of purified antibodies against human AFP-dextran-daunorubicin to human AFP-producing yolk sac tumor cell lines. Cancer Immunol Immunother 22: 81-86, 1986.

16. Tsukada Y, Ohkawa K and Hibi N: Therapeutic effect of treatment with polyclonal or monoclonal antibodies to alpha-fetoprotein that have been conjugated to daunomycin via a dextran bridge: Studies with an alpha-fetoprotein-producing rat hepatoma tumor model. Cancer Res 47: 4293-4295, 1987.

17. Ohkawa K, Tsukada Y, Hibi N, Umemoto N and Hara T: Selective in vitro and in vivo growth inhibition against human yolk sac tumor cell lines by purified antibody against human alpha-fetoprotein conjugated with mitomycin $\mathrm{C}$ via human serum albumin. Cancer Immunol Immunother 23: 81-86, 1986.

18. Kim EE, DeLand FH, Nelson MO, Bennett S, Simmons G, Alpert E and Goldenberg DM: Radioimmunodetection of cancer with radiolabeled antibodies to alpha-fetoprotein. Cancer Res 40: 3008-3012, 1980.

19. Kim EE, Deland FH, Casper S, Corgan RL, Primus FJ and Goldenberg DM: Radioimmunodetection of colorectal cancer. Cancer 45 (Suppl): 1243-1247, 1980.

20. Uriel J, Villacampa MJ, Moro R, Naval J and Failly-Crépin C: Uptake of radiolabeled $\alpha$-fetoprotein by mouse mammary carcinomas and its usefulness in tumor scintigraphy. Cancer Res 44: 5314-5319, 1984.

21. Goldenberg DM: Cancer imaging with CEA antibodies: Historical and current perspectives. Int J Biol Markers 7: 183-188, 1992.

22. Behr TM, Liersch T, Greiner-Bechert L, Griesinger F, Béhé M, Markus PM, Gratz S, Angerstein C, Brittinger G, Becker H, et al: Radioimmunotherapy of small-volume disease of metastatic colorectal cancer. Cancer 94 (Suppl): 1373-1381, 2002.

23. Aarts F, Boerman OC, Sharkey RM, Hendriks T, Chang CH, McBride WJ, Bleichrodt RP, Oyen WJ and Goldenberg DM: Pretargeted radioimmunoscintigraphy in patients with primary colorectal cancer using a bispecific anticarcinoembryonic antigen CEA X anti-di-diethylenetriaminepentaacetic acid $\mathrm{F}\left(\mathrm{ab}^{\prime}\right) 2$ antibody. Cancer 116 (Suppl): 1111-1117, 2010.

24. Mizejewski GJ: Biological role of alpha-fetoprotein in cancer: Prospects for anticancer therapy. Expert Rev Anticancer Ther 2: 709-735, 2002.

25. Li MS, Li PF, Yang FY, He SP, Du GG and Li G: The intracellular mechanism of alpha-fetoprotein promoting the proliferation of NIH 3T3 cells. Cell Res 12: 151-156, 2002.

26. Li MS, Li PF, He SP, Du GG and Li G: The promoting molecular mechanism of alpha-fetoprotein on the growth of human hepatoma Bel7402 cell line. World J Gastroenterol 8: 469-475, 2002.

27. Li P, Wang SS, Liu H, Li N, McNutt MA, Li G and Ding HG: Elevated serum alpha fetoprotein levels promote pathological progression of hepatocellular carcinoma. World J Gastroenterol 17: 4563-4571, 2011.

28. Moro R, Gulyaeva-Tcherkassova J and Stieber P: Increased alpha-fetoprotein receptor in the serum of patients with earlystage breast cancer. Curr Oncol 19: e1-e8, 2012. 
29. Wang S, Jiang W, Chen X, Zhang C, Li H, Hou W, Liu Z, McNutt MA, Lu F and Li G: Alpha-fetoprotein acts as a novel signal molecule and mediates transcription of Fn14 in human hepatocellular carcinoma. J Hepatol 57: 322-329, 2012.

30. Zhu M, Lin B, Zhou P and Li M: Molecular analysis of AFP and HSA interactions with PTEN potein. BioMed Res Int 2015 256916, 2015.

31. Mizejewski GJ: Nonsecreted cytoplasmic alpha-fetoprotein: A newly discovered role in intracellular signaling and regulation. An update and commentary. Tumour Biol 36: 9857-9864, 2015.

32. Li M, Li H, Li C, Wang S, Jiang W, Liu Z, Zhou S, Liu X, McNutt MA and Li G: Alpha-fetoprotein: A new member of intracellular signal molecules in regulation of the PI3K/AKT signaling in human hepatoma cell lines. Int J Cancer 128 524-532, 2011.

33. Gao R, Cai C, Gan J, Yang X, Shuang Z, Liu M, Li S and Tang H: miR-1236 down-regulates alpha-fetoprotein, thus causing PTEN accumulation, which inhibits the PI3K/Akt pathway and malignant phenotype in hepatoma cells. Oncotarget 6 : 6014-6028, 2015 .

34. Zhu M, Guo J, Li W, Lu Y, Fu S, Xie X, Xia H, Dong X, Chen Y, Quan $\mathrm{M}$, et al: Hepatitis B virus X protein induces expression of alpha-fetoprotein and activates $\mathrm{PI} 3 \mathrm{~K} / \mathrm{mTOR}$ signaling pathway in liver cells. Oncotarget 6: 12196-12208, 2015

35. Su R, Nan H, Guo H, Ruan Z, Jiang L, Song Y and Nan K: Associations of components of PTEN/AKT/mTOR pathway with cancer stem cell markers and prognostic value of these biomarkers in hepatocellular carcinoma. Hepatol Res 46: 1380-1391, 2016.

36. Zhu M, Guo J, Xia H, Li W, Lu Y, Dong X, Chen Y, Xie X, Fu S and Li M: Alpha-fetoprotein activates AKT/mTOR signaling to promote CXCR4 expression and migration of hepatoma cells. Oncoscience 2: 59-70, 2015.

37. Ji X, Shen Y, Sun H and Gao X: A novel anti-alpha-fetoprotein single-chain variable fragment displays anti-tumor effects in HepG 2 cells as a single agent or in combination with paclitaxel. Tumour Biol 37: 10085-10096, 2016.

38. Matsumoto M, Matsuura T, Aoki K, Maehashi H, Iwamoto T, Ohkawa K, Yoshida K, Yanaga K and Takada K: An efficient system for secretory production of fibrinogen using a hepatocellular carcinoma cell line. Hepatol Res 45: 315-325, 2015.

39. Nakabayashi H, Taketa K, Miyano K, Yamane T and Sato J: Growth of human hepatoma cells lines with differentiated functions in chemically defined medium. Cancer Res 42 : $3858-3863,1982$

40. Ohkawa K, Tsukada Y, Murae M, Kimura E, Takada K, Abe T, Terashima Y and Mitani K: Serum levels and biochemical characteristics of human ovarian carcinoma-associated antigen defined by murine monoclonal antibody, CF511. Br J Cancer 60 : 953-960, 1989.

41. Baumann H and Doyle D: Metabolic fate of cell surface glycoproteins during immunoglobulin-induced internalization. Cell 21: 897-907, 1980.

42. Press OW, Hansen JA, Farr A and Martin PJ: Endocytosis and degradation of murine anti-human CD3 monoclonal antibodies by normal and malignant T-lymphocytes. Cancer Res 48: 2249-2257, 1988.

43. Kyriakos RJ, Shih LB, Ong GL, Patel K, Goldenberg DM and Mattes MJ: The fate of antibodies bound to the surface of tumor cells in vitro. Cancer Res 52: 835-842, 1992.

44. McEwan WA, Tam JC, Watkinson RE, Bidgood SR, Mallery DL and James LC: Intracellular antibody-bound pathogens stimulate immune signaling via the Fc receptor TRIM21. Nat Immunol 14: 327-336, 2013

45. Watkinson RE, McEwan WA and James LC: Intracellular antibody immunity. J Clin Immunol 34 (Suppl 1): S30-S34, 2014

46. Yoshikawa M, Mukai Y, Okada Y, Tsumori Y, Tsunoda S, Tsutsumi Y, Aird WC, Yoshioka Y, Okada N, Doi T, et al: Robo4 is an effective tumor endothelial marker for antibody-drug conjugates based on the rapid isolation of the anti-Robo4 cellinternalizing antibody. Blood 121: 2804-2813, 2013.

47. Ha KD, Bidlingmaier SM, Su Y, Lee NK and Liu B: Identification of novel macropinocytosing human antibodies by phage display and high-content analysis. Methods Enzymol 585: 91-110, 2017.

48. Miura K, Law SW, Nishi S and Tamaoki T: Isolation of alphafetoprotein messenger RNA from mouse yolk sac. J Biol Chem 254: 5515-5521, 1979.

49. Zhou BP, Liao Y, Xia W, Spohn B, Lee MH and Hung MC: Cytoplasmic localization of $\mathrm{p} 21^{\mathrm{Cip} 1 / \mathrm{WAF} 1}$ by Akt-induced phosphorylation in HER-2/neu-overexpressing cells. Nat Cell Biol 3: 245-252, 2001
50. Chung JH and Eng C: Nuclear-cytoplasmic partitioning of phosphatase and tensin homologue deleted on chromosome 10 (PTEN) differentially regulates the cell cycle and apoptosis. Cancer Res 65: 8096-8100, 2005.

51. Chung JH, Ginn-Pease ME and Eng C: Phosphatase and tensin homologue deleted on chromosome 10 (PTEN) has nuclear localization signal-like sequences for nuclear import mediated by major vault protein. Cancer Res 65: 4108-4116, 2005.

52. Chung JH, Ostrowski MC, Romigh T, Minaguchi T, Waite KA and Eng C: The ERK1/2 pathway modulates nuclear PTENmediated cell cycle arrest by cyclin D1 transcriptional regulation. Hum Mol Genet 15: 2553-2559, 2006.

53. Gil A, Andrés-Pons A, Fernández E, Valiente M, Torres J, Cervera $\mathbf{J}$ and Pulido R: Nuclear localization of PTEN by a Ran-dependent mechanism enhances apoptosis: Involvement of an $\mathrm{N}$-terminal nuclear localization domain and multiple nuclear exclusion motifs. Mol Biol Cell 17: 4002-4013, 2006.

54. Al-Khouri AM, Ma Y, Togo SH, Williams S and Mustelin T: Cooperative phosphorylation of the tumor suppressor phosphatase and tensin homologue (PTEN) by casein kinases and glycogen synthase kinase 3beta. J Biol Chem 280: 35195-35202, 2005.

55. Tamguney T and Stokoe D: New insights into PTEN. J Cell Sci 120: 4071-4079, 2007

56. Georgescu MM, Kirsch KH, Akagi T, Shishido T and Hanafusa H: The tumor-suppressor activity of PTEN is regulated by its carboxyl-terminal region. Proc Natl Acad Sci USA 96: 10182-10187, 1999.

57. Tolkacheva T and Chan AM: Inhibition of H-Ras transformation by the PTEN/MMAC1/TEP1 tumor suppressor gene. Oncogene 19: $680-689,2000$

58. Maccario H, Perera NM, Davidson L, Downes CP and Leslie NR: PTEN is destabilized by phosphorylation on Thr366. Biochem J 405: 439-444, 2007.

59. Torres J and Pulido R: The tumor suppressor PTEN is phosphorylated by the protein kinase CK 2 at its $C$ terminus. Implications for PTEN stability to proteasome-mediated degradation. J Biol Chem 276: 993-998, 2001

60. Milella M,Falcone I,Conciatori F, Cesta Incani U, Del Curatolo A, Inzerilli N, Nuzzo CM, Vaccaro V, Vari S, Cognetti F, et al: PTEN: Multiple functions in human malignant tumors. Front Oncol 5: 24, 2015

61. Vazquez F, Ramaswamy S, Nakamura N and Sellers WR: Phosphorylation of the PTEN tail regulates protein stability and function. Mol Cell Biol 20: 5010-5018, 2000.

62. Birle D, Bottini N, Williams S, Huynh H, deBelle I, Adamson E and Mustelin T: Negative feedback regulation of the tumor suppressor PTEN by phosphoinositide-induced serine phosphorylation. J Immunol 169: 286-291, 2002.

63. Okahara F, Ikawa H, Kanaho Y and Maehama T: Regulation of PTEN phosphorylation and stability by a tumor suppressor candidate protein. J Biol Chem 279: 45300-45303, 2004.

64. Okahara F, Itoh K, Nakagawara A, Murakami M, Kanaho Y and Maehama T: Critical role of PICT-1, a tumor suppressor candidate, in phosphatidylinositol 3,4,5-trisphosphate signals and tumorigenic transformation. Mol Biol Cell 17: 4888-4895, 2006.

65. Doble BW and Woodgett JR: GSK-3: Tricks of the trade for a multi-tasking kinase. J Cell Sci 116: 1175-1186, 2003.

66. Saini MK and Sanyal SN: PTEN regulates apoptotic cell death through PI3-K/Akt/GSK3 $\beta$ signaling pathway in DMH induced early colon carcinogenesis in rat. Exp Mol Pathol 93: 135-146, 2012.

67. Tibarewal P, Zilidis G, Spinelli L, Schurch N, Maccario H, Gray A, Perera NM, Davidson L, Barton GJ and Leslie NR: PTEN protein phosphatase activity correlates with control of gene expression and invasion, a tumor-suppressing phenotype, but not with AKT activity. Sci Signal 5: ra18, 2012.

68. Freeman DJ, Li AG, Wei G, Li HH, Kertesz N, Lesche R, Whale AD, Martinez-Diaz H, Rozengurt N, Cardiff RD, et al: PTEN tumor suppressor regulates p53 protein levels and activity through phosphatase-dependent and -independent mechanisms. Cancer Cell 3: 117-130, 2003.

69. Li AG, Piluso LG, Cai X, Wei G, Sellers WR and Liu X: Mechanistic insights into maintenance of high $\mathrm{p} 53$ acetylation by PTEN. Mol Cell 23: 575-587, 2006.

70. Hupp TR, Meek DW, Midgley CA and Lane DP: Regulation of the specific DNA binding function of p53. Cell 71: 875-886, 1992.

71. Sakaguchi K, Sakamoto H, Lewis MS, Anderson CW, Erickson JW, Appella E and Xie D: Phosphorylation of serine 392 stabilizes the tetramer formation of tumor suppressor protein p53. Biochemistry 36: 10117-10124, 1997. 
72. Shieh SY, Taya Y and Prives C: DNA damage-inducible phosphorylation of p53 at N-terminal sites including a novel site, Ser20, requires tetramerization. EMBO J 18: 1815-1823, 1999.

73. Oda K, Arakawa H, Tanaka T, Matsuda K, Tanikawa C, Mori T, Nishimori H, Tamai K, Tokino T, Nakamura Y, et al: p53AIP1, a potential mediator of p53-dependent apoptosis, and its regulation by Ser-46-phosphorylated p53. Cell 102: 849-862, 2000.

74. Hirao A, Kong YY, Matsuoka S, Wakeham A, Ruland J, Yoshida H, Liu D, Elledge SJ and Mak TW: DNA damageinduced activation of $\mathrm{p} 53$ by the checkpoint kinase Chk2. Science 287: 1824-1827, 2000

75. Haupt Y, Maya R, Kazaz A and Oren M: Mdm2 promotes the rapid degradation of p53. Nature 387: 296-299, 1997.

76. Mayo LD and Donner DB: A phosphatidylinositol 3-kinase/Akt pathway promotes translocation of Mdm2 from the cytoplasm to the nucleus. Proc Natl Acad Sci USA 98: 11598-11603, 2001.

77. Zhou BP, Liao Y, Xia W, Zou Y, Spohn B and Hung MC: HER-2/ neu induces p53 ubiquitination via Akt-mediated MDM2 phosphorylation. Nat Cell Biol 3: 973-982, 2001.

78. Morani F, Phadngam S, Follo C, Titone R, Aimaretti G, Galetto A, Alabiso $\mathrm{O}$ and Isidoro $\mathrm{C}$ : PTEN regulates plasma membrane expression of glucose transporter 1 and glucose uptake in thyroid cancer cells. J Mol Endocrinol 53: 247-258, 2014.

79. Samih N, Hovsepian S, Aouani A, Lombardo D and Fayet G: Glut-1 translocation in FRTL-5 thyroid cells: Role of phosphatidylinositol 3-kinase and N-glycosylation. Endocrinology 141: 4146-4155, 2000.

80. Hajduch E, Litherland GJ and Hundal HS: Protein kinase B (PKB/Akt) - a key regulator of glucose transport? FEBS Lett 492: 199-203, 2001

81. Ciampi R, Vivaldi A, Romei C, Del Guerra A, Salvadori P, Cosci B, Pinchera A and Elisei R: Expression analysis of facilitative glucose transporters (GLUTs) in human thyroid carcinoma cell lines and primary tumors. Mol Cell Endocrinol 291: 57-62, 2008.

82. Wang CH, Wey KC, Mo LR, Chang KK, Lin RC and Kuo JJ: Current trends and recent advances in diagnosis, therapy, and prevention of hepatocellular carcinoma. Asian Pac J Cancer Prev 16: 3595-3604, 2015.

83. Taketomi A: Clinical trials of antiangiogenic therapy for hepatocellular carcinoma. Int J Clin Oncol 21: 213-218, 2016.

84. Dhir M, Melin AA, Douaiher J, Lin C, Zhen WK, Hussain SM, Geschwind JF, Doyle MB, Abou-Alfa GK and Are C: A review and update of treatment options and controversies in the management of hepatocellular carcinoma. Ann Surg 263: 1112-1125, 2016.
85. Lin J, Wu L, Bai X, Xie Y, Wang A, Zhang H, Yang X, Wan X, Lu X, Sang X, et al: Combination treatment including targeted therapy for advanced hepatocellular carcinoma. Oncotarget 7: 71036-71051, 2016

86. Nakata K, Muro T, Furukawa R, Kono K, Kusumoto Y, Ishii N, Munehisa T, Koji T and Nagataki S: Presence of immunoglobulin $\mathrm{G}$ in human sera binding to alphafetoprotein. Oncodev Biol Med 4: C101-C104, 1983

87. Asano T, Yamada N, Ochiai T, Sato H and Fukao T: Presence of anti-AFP-antibody producing B cells in peripheral blood lymphocyte of hepatocellular carcinoma patient. Nihon Shokakibyo Gakkai Zasshi 81: 278, 1984 (In Japanese).

88. Sassi F, Ayed K, el Gaied A and Dellagi K: Presence of antialphafetoprotein immunoglobulin $\mathrm{G}$ in serum of a patient with hepatocellular carcinoma]. Gastroenterol Clin Biol 15: 661-662, 1991 (in French)

89. Liu H, Zhang J, Wang S, Pang Z, Wang Z, Zhou W and Wu M: Screening of autoantibodies as potential biomarkers for hepatocellular carcinoma by using T7 phase display system. Cancer Epidemiol 36: 82-88, 2012.

90. Negm OH, Hamed MR, Schoen RE, Whelan RL, Steele RJ, Scholefield J, Dilnot EM, Shantha Kumara HM, Robertson JF and Sewell HF: Human blood autoantibodies in the detection of colorectal cancer. PLoS One 11: e0156971, 2016.

91. Ura Y, Ochi Y, Hamazu M, Ishida M, Nakajima $K$ and Watanabe T: Studies on circulating antibody against carcinoembryonic antigen (CEA) and CEA-like antigen in cancer patients. Cancer Lett 25: 283-295, 1985

92. Konstadoulakis MM, Syrigos KN, Albanopoulos C, Mayers G and Golematis B: The presence of anti-carcinoembryonic antigen (CEA) antibodies in the sera of patients with gastrointestinal malignancies. J Clin Immunol 14: 310-313, 1994.

93. Haidopoulos D, Konstadoulakis MM, Antonakis PT, Alexiou DG, Manouras AM, Katsaragakis SM and Androulakis GF: Circulating anti-CEA antibodies in the sera of patients with breast cancer. Eur J Surg Oncol 26: 742-746, 2000.

94. Ladd J, Lu H, Taylor AD, Goodell V, Disis ML and Jiang S: Direct detection of carcinoembryonic antigen autoantibodies in clinical human serum samples using a surface plasmon resonance sensor. Colloids Surf B Biointerfaces 70: 1-6, 2009.

95. Zhu M, Li W, Lu Y, Dong X, Lin B, Chen Y, Zhang X, Guo J and $\mathrm{Li}$ M: HBx drives alpha fetoprotein expression to promote initiation of liver cancer stem cells through activating PI3K/AKT signal pathway. Int J Cancer 140: 1346-1355, 2017. 